KORNELIA CZERWIŃSKA

Wydział Nauk Pedagogicznych

Akademia Pedagogiki Specjalnej

Warszawa
Forum Pedagogiczne $2016 / 1$

Wpłynęło: 28.11.2015 Zatwierdzono do druku: 7.03.2016

\title{
FUNKCJONOWANIE OSOBY STOPNIOWO TRACACEJ WZROK W PRZESTRZENI EDUKACYJNO-REHABILITACYJNEJ
}

Streszczenie: Tekst składa się z dwóch podstawowych części. W pierwszej zawarto teoretyczną analizę wpływu wrodzonej niepełnosprawności progresywnej na bieg życia, ze szczególnym zwróceniem uwagi na takie obszary, jak edukacja i funkcjonowanie społeczne. $\mathrm{W}$ drugiej zaś opisano indywidualny przypadek przebiegu edukacji osoby z postępującą słabowzrocznością na tle przemian polityczno-społecznych, jakie miały miejsce w Polsce w ostatnich czterech dekadach.

Słowa kluczowe: niepełnosprawność wzroku, utrata wzroku, edukacja, rehabilitacja

\section{Wprowadzenie}

Współczesna krajowa przestrzeń edukacyjna charakteryzuje się różnorodnością form, w jakich może być realizowane kształcenie uczniów $\mathrm{z}$ niepełnosprawnością. Kształcenie specjalne, traktowane jako specjalistyczna usługa edukacyjna, może odbywać się zarówno na terenie placówek specjalnych i integracyjnych, jak i w tzw. szkołach głównego nurtu (edukacja włączająca). Od czasu utworzenia pierwszych szkół specjalnych przeznaczonych dla uczniów z określonym rodzajem niepełnosprawności kształcenie specjalne uległo znacznym przeobrażeniom ilościowym i jakościowym (Chrzanowska 2015; Marcinkowska 2015). W przypadku edukacji uczniów z niepełnosprawnością wzroku zauważalny jest stały wzrost liczby uczęszczających do szkół integracyjnych i ogólnodostępnych, przy czym dotyczy on głównie dzieci słabowidzących. Widoczne są także przeobrażenia w celach i funkcjach specjalnych ośrodków szkolno-wychowawczych dla uczniów z tym typem dysfunkcji, związane ze zmianami w populacji podopiecznych (wzrostem liczby uczniów niewidomych i słabowidzących z dodatkowymi niepełnosprawnościami) oraz narastającą potrzebą udzielania profesjonalnego wsparcia tyflopedagogicznego nauczycielom i uczniom z placówek ogólnodostępnych (Czerwińska 2014b). 
Kształcenie specjalne, niezależnie od rodzaju placówki szkolnej, w której jest realizowane, musi gwarantować wysoką jakość warunków dydaktycznych, dostosowanych do potrzeb i możliwości uczniów ze specjalnymi potrzebami edukacyjnymi (Dycht 2015; Głodkowska 2013). Psychologiczna sytuacja takich uczniów nosi znamiona utrudnienia - możliwość efektywnego wypełniania przez nich swojej roli jest mniejsza ze względu na różnorodne deficyty (braki). Z powodu niepełnosprawności potrzebują oni innego podejścia pedagogicznego niż standardowe, zastosowania zindywidualizowanych strategii dydaktycznych, wykorzystania zmodyfikowanych pomocy naukowych, wprowadzenia dodatkowych udogodnień (Brzezińska i in. 2014). Warunki niezbędne do osiągnięcia sukcesu edukacyjnego przez tę kategorię uczniów zależne są w dużej mierze od rodzaju i stopnia danej dysfunkcji. W szczególnie trudnej sytuacji rozwojowej znajdują się ci, których niepełnosprawność ma charakter progresywny.

\section{Stopniowa utrata wzroku a edukacja}

Mimo iż efektem ustabilizowanej i progresywnej niepełnosprawności wzroku mogą być ograniczenia obiektywnie do siebie podobne, np. trudności w orientacji przestrzennej i samodzielnym poruszaniu się, to jednak ich psychologiczne i funkcjonalne implikacje odznaczają się pewną specyfiką. Przebieg schorzeń postępujących, leżących u podłoża dysfunkcji wzroku, jest trudny do przewidzenia, stąd niełatwo jest ocenić jego bezpośredni wpływ na drogę edukacyjną danego ucznia i zaplanować optymalne wsparcie. Czynnik uszkadzający pojawia się w różnych momentach życia, prowadząc do nasilenia dotychczasowych trudności doświadczanych przez słabowidzącego ucznia lub do wystąpienia nowych deficytów (Łuba 2015). Możliwości wzrokowe ucznia z progresywną słabowzrocznością zmieniają się dynamicznie w czasie, więc system pomocy pedagogicznej musi mieć charakter elastyczny i natychmiast reagować na każdy przejaw pogorszenia się stanu wzroku; stałe modyfikowanie rodzaju i zakresu udzielanego wsparcia gwarantuje, że warunki kształcenia będą odpowiadały aktualnym potrzebom dziecka.

Rozwój uczniów z postępującą słabowzrocznością nie przebiega według jednego uniwersalnego wzorca, jednak można wskazać pewne typy doświadczeń związanych ze zdobywaniem wykształcenia, które zazwyczaj podzielane są przez wszystkich członków tej grupy, choć w różnym stopniu. Charakter schorzenia układu wzrokowego implikuje konieczność bycia pod stałą opieką lekarską, częstego konsultowania się u okulistów, poddania się leczeniu (terapii farmakologicznej, licznym operacjom zapobiegającym dalszej utracie wzroku), co na ogół wiąże się z potrzebą hospitalizacji i wydłużonego okresu rekonwalescencji, w czasie których uczeń jest nieobecny w szkole (Zaorska 2015). Częste i długotrwałe absencje skutkują trudnościami w opanowaniu wymaganego materiału, zwłaszcza że funkcjonalną konsekwencją słabowzroczności jest także stosunkowo wolne tempo pracy i zwiększona męczliwość podczas aktywności wymagających zaangażowania 
wzroku. Nieobecność w szkole zwiększa ryzyko izolacji społecznej ucznia, prowadzi bowiem do rozluźnienia jego relacji z kolegami w klasie, uniemożliwia uczestniczenie w wielu wspólnych działaniach rówieśniczych, zarówno formalnych, jak i nieformalnych. Nie bez znaczenia dla funkcjonowania ucznia w szkole jest również bolesny charakter wielu zabiegów okulistycznych oraz liczne przeciwwskazania lekarskie do podejmowania określonych aktywności i zabaw.

Zmienność funkcjonalnych możliwości posługiwania się wzrokiem utrudnia dokonanie adekwatnej oceny posiadanego potencjału. Lęk przed całkowitą utratą wzroku prowadzi niejednokrotnie do nieuzasadnionych zachowań asekuracyjnych, nadmiernej ostrożności i niepodejmowania nowych wyzwań. Nadzieja na poprawę funkcji wzrokowych, często łącząca się z mechanizmami zaprzeczenia i wyparcia, sprzyja z kolei przeszacowywaniu swoich możliwości wzrokowych, czasami graniczącemu z ryzykanctwem (Zaorska 2015). Brak akceptacji własnych ograniczeń przejawia się aktywnymi strategiami zachowań ukierunkowanych na ukrycie przed otoczeniem osłabionego widzenia. Obserwacje prowadzone przez rodziców i nauczycieli uczniów z tym typem dysfunkcji wzroku wskazują, że dzieci w wielu przypadkach twierdzą, że coś dostrzegają, mimo że nie jest to zgodne z prawdą i poddane weryfikacji ujawnia rzeczywiste problemy wzrokowe (Smith 2008). Pedagodzy stoją więc wobec szczególnego zadania, jakim jest stałe określanie sposobu i stopnia, w jakim dany uczeń może wykorzystywać wzrok w procesie kształcenia. Wyniki takiej permanentnej oceny decydują o dostosowaniu metod i środków dydaktycznych do indywidualnych potrzeb dziecka słabowidzącego. Należy przy tym pamiętać, że sytuację dodatkowo komplikuje duża zmienność warunków zewnętrznych (oświetlenie, pora dnia, kolorystyka i kontrast obiektów, organizacja przestrzeni itp.) i czynników osobowych (aktualna kondycja psychofizyczna, okresowe fluktuacje widzenia itp.), która sprawia, że dotychczas stosowane metody nauczania i strategie uczenia się mogą przestać być efektywne. Dobór odpowiednich technik realizacji zadań (techniki wzrokowe $v$. alternatywne techniki bezwzrokowe oparte na dotyku i słuchu) wymaga ciągłej uwagi, elastyczności w działaniu i kreatywności ze strony nauczyciela i samego ucznia (Czerwińska 2014a). W organizacji warunków kształcenia przyjmuje się zasadę optymalnego wykorzystywania potencjału wzrokowego ucznia, czyli posługiwania się wzrokiem we wszystkich sytuacjach, w których zmysł ten umożliwia skuteczne, bezpieczne i szybkie wykonanie zadania. W pozostałych przypadkach zaleca się stosowanie technik kompensujących braki sensoryczne, wykorzystujących inne zmysły, głównie słuch i dotyk. W początkowych etapach edukacyjnych uczniowie z postępującą słabowzrocznością zazwyczaj piszą i czytają drogą wzrokową, korzystając przy tym z materiałów szkolnych zaadaptowanych do ich możliwości percepcyjnych, pomocy optycznych i nieoptycznych wspomagających widzenie i/ lub adaptacji otoczenia fizycznego. Progres schorzenia powoduje często konieczność zmiany technik szkolnych na takie, które są oparte na dotyku, wymagają dobrej znajomości systemu Braille’a bądź wykorzystują słuch, a więc udźwiękowionych 
pomocy informatycznych. Uznaje się, że adaptacja do kolejnego etapu utraty funkcji wzrokowych jest łatwiejsza wówczas, gdy w procesie edukacji sukcesywnie rozwijane są umiejętności kluczowe dla sprawnego funkcjonowania w sytuacji całkowitego niewidzenia (m.in. obsługa sprzętu komputerowego i oprogramowania dla niewidomych, nauka orientacji przestrzennej i samodzielnego poruszania się). Zarazem pojawiają się analizy badawcze (Gołębiowska, Bargiel-Matusiewicz 2015) dowodzące, że długotrwały stres związany z postępującą chorobą wiąże się z niższym prawdopodobieństwem wystąpienia pozytywnych zmian rozwojowych, niż ma to miejsce w przypadku silnego stresu, który trwa krócej.

Za specyficzne dla grupy uczniów z postępującą dysfunkcją wzroku uznaje się również trudności w kształtowaniu tożsamości w wymiarze osobistym i społecznym. Ta kategoria osób określana jest mianem ludzi pogranicza, posiadają oni pewne swoiste właściwości w sposób mniej lub bardziej wyraźny odróżniające ich od osób pełnosprawnych wzrokowo i całkowicie niewidomych. Zdarza się, że charakterystyka tożsamościowa takich uczniów ma charakter sytuacyjny i jest wypracowywana na drodze negocjacji; w pewnych okolicznościach postrzegają oni siebie i są identyfikowani przez otoczenie jako należący do jednej z możliwych kategorii (osoby widzące, słabowidzące lub niewidome), w innych przypadkach kategoria ta się zmienia na inną (w ramach wspomnianego podziału), a w jeszcze innych identyfikacje $\mathrm{z}$ tymi kategoriami tracą zupełnie na znaczeniu (Melchior $2008)^{1}$.

\section{Droga edukacyjna osoby stopniowo tracącej wzrok - opis przypadku}

Dla populacji osób doświadczających wrodzonej niepełnosprawności wzroku o charakterze progresywnym charakterystyczne jest znaczne zróżnicowanie drogi rozwojowej, uwarunkowane szeregiem wzajemnie powiązanych czynników osobowych i środowiskowych. Zmienne istotnie wpływające na kształt procesu edukacji takich osób są tak liczne, złożone i zarazem mocno spersonalizowane, że czynią zasadne przyjęcie w analizach badawczych perspektywy jakościowej. W celu poznania, opisu i analizy przebiegu ścieżki edukacyjnej osoby z tym rodzajem dysfunkcji zastosowano więc metodę indywidualnego przypadku, w której podstawową techniką gromadzenia danych był biograficzny wywiad narracyjny, przeprowadzony przez autorkę niniejszego artykułu z 45-letnim mężczyzną z postępującą słabowzrocznością. Dodatkowe informacje zostały pozyskane z częściowo ustrukturalizowanych wywiadów udzielonych przez osoby, mające w różnych fazach życia badanego

1 Trudności w jednoznacznym odniesieniu stanu słabowzroczności do konkretnych aspektów tożsamości jednostkowej widoczne były także w narracjach osoby badanej, której przypadek został opisany w niniejszym tekście. Swoisty zamęt tożsamościowy doświadczany był przez badanego zarówno w okresie dorastania, jak i dorosłości. 
znaczący wpływ na jego edukację (starszy brat, nauczyciele ze szkoły podstawowej, kolega szkolny, córka).

Analiza dokumentacji medycznej wykazała, że w 6. miesiącu życia u badanego zdiagnozowano wrodzoną zaćmę obuoczną. W ciągu pierwszych trzech lat życia został on poddany ponad sześciu operacjom okulistycznym. W okresie dorastania badania ujawniły pojawienie się wtórnej postaci jaskry, początkowo w oku lewym, później w obu gałkach. Na skutek postępującego procesu chorobowego mężczyzna w trakcie studiów utracił całkowicie wzrok w lewym oku, w prawym zaś doszło do znacznego obniżenia ostrości widzenia.

Mimo pewnych obaw ze strony rodziców, dotyczących możliwości sprostania wymogom szkoły masowej, badany rozpoczął swoją edukację w placówce ogólnodostępnej. Szkoła nie dysponowała pomocami dydaktycznymi dostosowanymi do potrzeb percepcyjnych ucznia słabowidzącego, a nauczyciele nie posiadali nawet elementarnej wiedzy na temat wpływu dysfunkcji wzroku na proces uczenia się. Źródłem informacji o trudnościach doświadczanych przez badanego w trakcie nauki oraz możliwościach ich przezwyciężania stali się dla pracowników szkoły rodzice badanego. Dzięki ich stałej współpracy z nauczycielami, intensywnej pracy w domu rodzinnym nad rozwijaniem podstawowych umiejętności szkolnych (czytania, pisania, liczenia) oraz wysokiemu poziomowi motywacji własnej uzyskiwał on w pierwszych klasach szkoły podstawowej oceny bardzo dobre. Wyjątek stanowiły zajęcia $\mathrm{z}$ wychowania fizycznego, na których brak pełnej kontroli wzrokowej otoczenia implikował problemy podczas aktywnego uczestnictwa w zabawach i grach zespołowych; należy dodać, że nauczyciel wymagał od ucznia zdjęcia okularów na czas trwania zajęć, co skutkowało dalszym obniżeniem możliwości posługiwania się przez chłopca wzrokiem. Brak wsparcia tyflopedagogicznego okazał się szczególnie dotkliwy dla badanego w starszych klasach szkoły podstawowej. W tym okresie doszło do kolejnego pogorszenia się stanu wzroku, co na poziomie codziennego funkcjonowania uwidaczniało się zwłaszcza w zawężeniu pola widzenia w obszarach obwodowych oraz obniżeniu ostrości wzroku. Chłopiec zaczął wówczas po raz pierwszy odczuwać trudności w zakresie orientacji w większej przestrzeni i szybkiego reagowania na zmiany następujące w otoczeniu; problemy te okazały się istotne także dlatego, że nauka odbywała się już nie w jednej sali, lecz w różnych pomieszczeniach, do których należało szybko i samodzielnie przemieszczać się w czasie przerw. W opinii badanego czynnikiem, który w największym stopniu wpłynął na wyraźne pogorszenie się jego wyników w nauce w tym okresie, była niewiedza nauczycieli i ich niechęć do odejścia od standardowego sposobu nauczania.

Najbardziej chyba zacząłem być świadomy swoich problemów ze wzrokiem i związanych $\mathrm{z}$ nimi trudności w nauce gdzieś w drugiej połowie szkoły podstawowej. Gdzieś w 5-6 klasie, gdzie to już nauczyciele przedmiotowi zmieniali się, nie było jednego nauczyciela, który znał mnie, wiedział, jakie 
mam problemy i w jakiś sposób tam mi trochę pomagał. Ci nowi nauczyciele niekoniecznie wiedzieli, z czym mam problem, też nie do końca potrafili sobie $\mathrm{z}$ moimi trudnościami poradzić. Poza tym wymagania też były już wyższe - trzeba było więcej czytać, teksty były dłuższe, trzeba było szukać różnych informacji... Ten problem wzrokowy zaczął się bardzo uwidaczniać.

Szczególnym przykładem braku zrozumienia indywidualnych trudności ucznia i obiektywnych ograniczeń wynikających ze słabowzroczności było zachowanie nauczyciela geografii, który - mimo udzielanych przez samego ucznia i jego rodziców informacji o obniżonej ostrości wzroku - wymagał od badanego wykonywania zadań na mapie wiszącej na ścianie sali lekcyjnej. Chłopiec nie potrafił wskazać na niej podawanych przez nauczyciela rzek, miast, krain geograficznych itp., i często otrzymywał ocenę niedostateczną. Pomimo wzmożonej pracy w domu dostawał słabe oceny z przedmiotów, które wymagały większego zaangażowania wzroku, tj. z języka polskiego, zajęć plastycznych, technicznych i wychowania fizycznego.

Miałem problem z przepisywaniem z tablicy, ale radziłem sobie tak, że na przykład pożyczałem zeszyty od moich kolegów i rodzice mi pomagali uzupełnić braki w notatkach. Generalnie w szkole podstawowej największy problem miałem cały czas z geografią, gdzie nauczyciele nie mogli zupełnie tego zrozumieć, że ja słabo widzę i nie poradzę sobie z mapą. Do dnia dzisiejszego nie mogę tego zrozumieć! Jestem nauczycielem, wiem, że uczeń ma problemy z widzeniem i ja każę mu wskazać na mapie rzecz, której on nie jest w stanie w życiu zobaczyć!? No, przecież to jest irracjonalne! Nie rozumiem tego. Do dzisiaj zresztą nie jestem w stanie zrozumieć zachowań tych nauczycieli. Przecież to nawet osoba niewykształcona potrafi zrozumieć taką rzecz, że się nie da zobaczyć. Nauczyciele tłumaczyli się, że program trzeba zrealizować i nie ma innej możliwości realizacji, jak tylko przez odczytywanie mapy. I to był mój największy problem - geografia. Z matematyką sobie radziłem, ale przeczytać na mapie nie dało się!

W tym okresie badany intensywnie wypracowywał rozmaite strategie postępowania, mające na celu ukrycie przed otoczeniem, zwłaszcza przed rówieśnikami, problemów ze wzrokiem. Wstydząc się posiadanych ograniczeń, chłopiec świadomie unikał podejmowania aktywności, które mogły je ujawnić. Niejednokrotnie gromadził wcześniej z różnych źródeł informacje na temat danego obiektu, człowieka czy sytuacji, które podawał później w obecności rówieśników, starając się w ten sposób tworzyć wrażenie osoby prawidłowo widzącej. Sytuacje szkolne, w których zamaskowanie wobec kolegów trudności ze wzrokiem okazywało się niemożliwe, stawały się dla badanego źródłem bardzo silnego stresu. W narracjach wskazuje on na stosunkowo częste doświadczanie dyskomfortu psychicznego, skrępowania, wstydu, smutku, upokorzenia i ogólnego poczucia odmienności. 
Obawa przed ujawnieniem problemów wzrokowych była na tyle duża, że na długie lata zablokowała możliwość korzystania z pomocy rehabilitacyjnej Polskiego Związku Niewidomych, która w tamtym okresie mogła być dla osoby słabowidzącej uczęszczającej do szkół masowych niezwykle pomocna. Jednocześnie należy zauważyć, że ówczesna oferta największej polskiej organizacji działającej na rzecz osób z dysfunkcją wzroku nie miała charakteru zindywidualizowanego - badanemu zaproponowano naukę technik uczenia się i poruszania typowych dla osób niewidomych, nie zapewniono natomiast kontaktu z psychologiem $\mathrm{w}$ celu pracy nad zwiększeniem akceptacji własnych ograniczeń.

Rodzice zapisali mnie do Polskiego Związku Niewidomych, jak miałem tak mniej więcej z dziesięć lat. I tam proponowano mi, żebym się nauczył brajla, ale przecież to było wtedy dla mnie nierealne. Ja chciałem być taki jak inni. Nie mogłem pokazywać w szkole, że ja źle widzę, ja się wtedy w ogóle nie wpisywałem w to, co w tym PZN było, co mi proponowano, to było nie dla mnie... I tak do trzydziestego któregoś roku życia ja tam się już więcej nie pojawiłem, na żadne spotkanie, na nic tam nie dałem się zaprosić.

Dalszy postęp procesu chorobowego nie wpłynął na decyzję chłopca i jego rodziców o kontynuacji nauki w jednym $\mathrm{z}$ najbardziej renomowanych w mieście liceów ogólnokształcących. Ze względu na niepełnosprawność wzroku badany został na wniosek wojewódzkiej poradni wychowawczo-zawodowej zwolniony z egzaminów wstępnych do szkoły średniej. Nauka w liceum sprawiała mu bardzo duże trudności z powodu wysokich wymagań przy jednoczesnym braku jakiegokolwiek wsparcia tyflopedagogicznego. Pedagodzy nie byli w żaden sposób przygotowani do pracy z uczniem stopniowo tracącym wzrok. Niektórzy z nich, bazując głównie na intuicji, starali się metodą prób i błędów wypracowywać optymalne dla badanego strategie prowadzenia zajęć, inni zaś uznawali, że to uczeń musi dostosować się do standardowych metod i środków nauczania. Podobnie jak w szkole podstawowej pojawił się problem z mapą niezaadaptowaną do możliwości percepcyjnych; nauczyciel geografii oświadczył, że uczeń albo opanuje jej czytanie, albo musi zmienić szkołę na placówkę specjalną.

W tym okresie konieczne stało się przeprowadzenie kolejnych zabiegów okulistycznych, gdyż wysoki poziom ciśnienia środgałkowego wywołany jaskrą nie mógł już być stabilizowany jedynie farmakologicznie. Dłuższa absencja w szkole związana z samą hospitalizacją i rekonwalescencją po operacjach skłoniła rodziców chłopca do wystąpienia z prośbą o przyznanie mu indywidualnego toku nauczania. Na podstawie dokumentacji lekarskiej i opinii poradni wychowawczo-zawodowej kuratorium oświaty wyraziło zgodę na taką formę kształcenia. Indywidualne lekcje odbywały się na terenie szkoły, ponadto chłopiec uczęszczał na wybrane zajęcia wraz z całą klasą, dzięki czemu zachowywał stały kontakt ze swoimi rówieśnikami. Zgodnie z ówczesnymi przepisami dotyczącymi nauczania 
indywidualnego został zwolniony z niektórych zajęć (wychowania plastycznego, wychowania technicznego, przysposobienia obronnego, wychowania fizycznego). Zdaniem badanego indywidualny tok nauczania na tym etapie edukacji okazał się bardzo dobrym rozwiązaniem: szybko uzupełnił zaległości w nauce, nauczyciele zaś zostali niejako zmuszeni do zmierzenia się z jego trudnościami wzrokowymi $\mathrm{w}$ procesie uczenia się.

Rodzice wystarali się o indywidualny tok nauczania dla mnie. I to było wtedy naprawdę dobre dla mnie rozwiązanie, na tamten moment oczywiście. Kiedy nauczyciel był ze mną sam na sam, to nie miał wyboru, on nie mógł mnie i moich problemów zignorować, on musiał mnie jakoś nauczyć, musiał znaleźć sposób. Kiedy siedziałem w klasie wśród innych, to nauczyciel mógł nie zwracać uwagi, że ja nie widzę tego, co on na tej mapie z daleka pokazuje, a teraz nie... I ten geograf wymyślił, sam wymyślił, jak mi tę mapę przybliżyć, ale wcześniej nie mógł wymyślić! Po pierwsze przyniósł atlas, a nie kazał mi oglądać mapy wielkiej, wiszącej na ścianie, po drugie przyniósł mi szkło powiększające [śmiech] i to tak wyglądało... metodą prób i błędów znajdował jakieś rozwiązania, o których wcześniej, gdy siedziałem w klasie z innymi, nawet nie pomyślał. To jest szokujące, prawda? Później już te wszystkie lekcje w trybie indywidualnym były dla mnie idealne.

W kolejnych latach badany także korzystał z indywidualnego toku nauki, wspomagając się zakupionymi w sklepie fotograficznym pomocami optycznymi, w tym lupą dobraną samodzielnie metodą prób i błędów. W narracjach dotyczących tego okresu kształcenia wyraża on głębokie zadowolenie z przyjętej formy edukacji. Po raz pierwszy przestał odczuwać obawę przed niepowodzeniami szkolnymi, gdyż tempo pracy było dostosowywane do jego indywidualnych możliwości, a nauczyciele starali się kompensować braki sensoryczne poprzez szczegółowe komentarze, dostarczanie dodatkowych informacji oraz modyfikowanie wykorzystywanych materiałów dydaktycznych. Istotny był również fakt, że realizowane osobno zajęcia nie doprowadziły do izolacji społecznej chłopca - w czasie przerw podejmował on działania wspólnie z rówieśnikami, wyjeżdżał na wszystkie wycieczki klasowe, w czasie wolnym od zajęć szkolnych spotykał się z kolegami². W końcowych latach nauki w liceum ponownie pojawiła się potrzeba dłuższej hospitalizacji z powodu

2 Zawarte w narracjach wątki dotyczące funkcjonowania społecznego osoby badanej zostały w niniejszym artykule - z uwagi na ograniczenia objętości i podstawowy cel opracowania - opisane w sposób skrótowy. Należy jednak zauważyć, że obrazy relacji międzyludzkich przedstawione w wywiadzie w pełni korespondują z wynikami badań jakościowych nad wspomnieniami szkoły z okresu PRL-u (Budziszewska i in. 2015). Pozytywnie wspominany jest czas spędzany z rówieśnikami, podkreślane jest poczucie wspólnoty i więzi koleżeńskich, a także wysoki poziom integracji wewnątrzklasowej, któremu sprzyjało kształcenie w trudnych warunkach. 
zabiegów ukierunkowanych na zahamowanie procesu dalszej utraty wzroku. Dzięki indywidualnej formie nauczania oraz wsparciu ze strony rodziców i starszego brata badany zdołał uzupełnić wszelkie zaległości wynikające z dłuższych nieobecności i przystąpił do egzaminu dojrzałości ze swoją klasą. Warto podkreślić, że podczas matury nie uwzględniono żadnych dostosowań związanych z posiadanym przez ucznia rodzajem niepełnosprawności (jak np. przedłużenie trwania egzaminu z uwagi na wydłużony czas pracy wzrokowej osoby słabowidzącej). Mimo nieuwzględnienia specjalnych potrzeb edukacyjnych badanego zdał on egzamin, uzyskując jako ogólny wynik ocenę dobrą.

Wybór dalszej drogi kształcenia okazał się dla niego niezwykle trudny. Niepełnosprawność, jak również świadomość postępującego charakteru schorzenia układu wzrokowego uniemożliwiały podjęcie wymarzonych studiów medycznych czy też wybór zawodu związanego z kierowaniem pojazdami. Charakterystyczny dla tego okresu powszechny brak dostosowania polskich uczelni do potrzeb osób z niepełnosprawnością wzmagał lęk badanego przed podjęciem próby studiowania psychologii. Obawiał się on, że z powodu osłabionego już znacznie widzenia nie będzie mógł w pełni korzystać z zajęć dydaktycznych realizowanych standardowymi metodami nauczania i w efekcie nie zdoła sprostać wymogom edukacji akademickiej. Decyzję o niepodejmowaniu studiów wyższych umocnił również fakt, że koledzy i znajomi wybierali kierunki, które nie leżały w kręgu zainteresowań badanego lub były dla niego nieodpowiednie z uwagi na typ posiadanej dysfunkcji. Ostatecznie zdecydował się on przyjąć propozycję zawartą w opinii o predyspozycjach zawodowych wydanej przez wojewódzką poradnię wychowawczo-zawodową i rozpoczął naukę w studium medycznym na kierunku praca socjalna. Uczęszczał tam wraz z innymi słuchaczami, bez przystosowania działań dydaktycznych do specjalnych potrzeb edukacyjnych, jednak w jego opinii właściwie żadne przystosowania nie były potrzebne, gdyż zajęcia odbywały się w formie wykładów, po serii których odbywał się egzamin ustny. Po uzyskaniu dyplomu mężczyzna zatrudnił się w ośrodku pomocy społecznej na stanowisku pracownika socjalnego.

Kolejne pogorszenie się stanu wzroku skłoniło badanego do nabycia kompetencji w zawodzie, który mógłby wykonywać w sytuacji całkowitej utraty widzenia. Równolegle z realizowaniem obowiązków zawodowych uczestniczył więc w 5-miesięcznym kursie masażu. Jego uczestnikami były osoby pełnosprawne, wykorzystywane materiały i pomoce dydaktyczne miały charakter wizualny, wśród metod nauczania dominował zaś pokaz czynności. Badany doświadczał więc znacznych trudności w przyswajaniu wiadomości i praktycznych umiejętności, jednak stosunkowo szybko nawiązał pozytywne relacje z innymi kursantami i dzięki ich pomocy oraz intensywnej pracy własnej ukończył kurs z wynikiem pozytywnym.

W niedługim czasie założył rodzinę i przeprowadził się do innego miasta, co wiązało się z koniecznością znalezienia nowej pracy. Uzyskanie zatrudnienia okazało się prawdziwym wyzwaniem, gdyż Polska była już wówczas po transformacjach polityczno-gospodarczych i w różnych regionach kraju zaczęło pojawiać 
się bezrobocie. Jednocześnie u badanego znów pogorszyło się funkcjonowanie wzroku. Niezbędne okazało się opanowanie nowych technik wykonywania wielu czynności, zarówno z obszaru samoobsługi, jak i korzystania ze sprzętu i narzędzi. Badany postanowił więc wziąć udział w turnusie rehabilitacyjnym przeznaczonym dla osób z dysfunkcją wzroku, w trakcie którego opanował m.in. techniki samodzielnego poruszania się w przestrzeni i bezwzrokowej obsługi komputera. W trakcie turnusu dał się poznać jako osoba ambitna, wytrwała, szybko ucząca się, łatwo nawiązująca kontakty. Organizatorzy turnusu złożyli mu propozycję dodatkowego szkolenia i nabycia kompetencji do pracy w charakterze asystenta technologicznego osoby z dysfunkcją wzroku. Po ukończeniu tego kursu badany został zatrudniony w Polskim Związku Niewidomych.

W 40. roku życia podjął decyzję o zapisaniu się na studia wyższe. W tym okresie studia w trybie niestacjonarnym rozpoczynała jego córka, uznał więc, że wspólna nauka będzie dla niego optymalnym rozwiązaniem. Mimo że dostępność wyższych uczelni dla osób słabowidzących i niewidomych była już w tym czasie dość duża, to nadal żywił on obawy, czy zdoła sprostać wymaganiom kształcenia akademickiego, i liczył na dyskretną pomoc córki w potencjalnie trudnych dla siebie sytuacjach. Córka uznała pomysł ojca za interesujący i wspólnie rozpoczęli naukę na kierunku pedagogika specjalna na jednej z poznańskich uczelni państwowych. Początkowo studiowali w tej samej grupie ćwiczeniowej, później jednak wybrali odmienne specjalności i badany stał się całkowicie niezależny w roli studenta.

W podjęciu przeze mnie studiów już w takim poważnym wieku dorosłym najważniejsza była motywacja. Przekonanie, że to mi się do czegoś przyda, że to jest $\mathrm{w}$ życiu potrzebne, plus przekonanie, że sobie dam radę. Takie podbudowanie siebie, że skoro inni mogą skończyć studia, to dlaczego nie ja. Ta psychologiczna strona decyzji o podjęciu studiów była chyba w moim przypadku najważniejsza. Poza tym zdawałem sobie sprawę z tego, że w tej chwili dzięki zdobyczom techniki, dzięki takim urządzeniom jak komputer $\mathrm{z}$ internetem, dyktafon itp. ta nauka jest łatwiejsza. Kiedyś na studiach wykładowca rzucał na ścianę czy ekran z diaskopu jakąś rycinę, schemat czy tekst... Mnie na przykład byłoby trudno to przeczytać. Dobrze jest, gdyby wykładowca opowiadał o tym, co jest wyświetlone. Ale są też wykładowcy, którzy rzucą jakiś tekst i uważają, że to jest wszystko, co student powinien wiedzieć, ja nie mógłbym tego przezrocza przeczytać. Teraz prezentacje są w wersjach elektronicznych, dostęp do nich jest łatwy, można różne materiały przekopiować na jakiś nośnik i zobaczyć na komputerze u siebie w domu, gdzie człowiek ma wszelkie udogodnienia i dostosowania do swojego osłabionego widzenia. Bardzo dużo z takich udogodnień korzystałem podczas studiów.

W trakcie studiów badany nagrywał wykłady i ćwiczenia na dyktafon, w domu sporządzał notatki, korzystając $\mathrm{z}$ udźwiękowionego komputera. W wielu przypadkach 
otrzymywał materiały dydaktyczne w wersjach elektronicznych, z których bez trudu mógł korzystać, posiłkując się posiadanym sprzętem informatycznym. Zaliczenia ćwiczeń i egzaminy w większości miały formę testową, która wymagała szybkiej analizy treści i zaznaczenia odpowiedzi lub opisu jakiegoś zjawiska. Badany zdawał wszystko w formie ustnej, ponieważ miał duże problemy z szybkim przeczytaniem testu, nawet $\mathrm{z}$ użyciem urządzenia powiększającego. Trudność sprawiało mu także odręczne pisanie. Ustna forma zaliczeń bardzo mu natomiast odpowiadała, gdyż dobrze znał ją z wcześniejszych doświadczeń edukacyjnych w szkole średniej i studium medycznym. Studia pierwszego stopnia ukończył w terminie, uzyskując na obronie pracy licencjackiej ocenę bardzo dobrą.

Odniesiony sukces zmotywował badanego do kontynuacji edukacji. W związku z tym, że pracował z osobami posiadającymi różne problemy wzrokowe, potrzebującymi fachowej pomocy, a także z powodu własnej niepełnosprawności, postanowił zdobyć wiedzę oraz dyplom tyflopedagoga w ramach niestacjonarnych studiów magisterskich. Realizacja tych planów wiązała się z koniecznością długich dojazdów do uczelni warszawskiej (ponad 6-godzinna podróż pociągiem); problematyczne wydawało się także samodzielne poruszanie się po tak dużym i nieznanym mieście. Mimo tych utrudnień badany zdecydował się na rozpoczęcie studiów. Kierując się wcześniejszymi doświadczeniami z uczelni poznańskiej, złożył wniosek do pełnomocnika studentów z niepełnosprawnością o udzielenie zgody na nagrywanie zajęć na dyktafon i na udostępnianie materiałów multimedialnych wykorzystywanych w czasie zajęć ze względu na swoją słabowzroczność. Analiza narracji dotyczących tego okresu edukacji wskazuje, że przebiegał on dość podobnie do studiów pierwszego stopnia. Warto odnotować, że badany wkładał bardzo wiele wysiłku w przyswojenie umiejętności, które pozwoliłyby mu na w pełni samodzielne podejmowanie wszystkich zadań związanych z rolą studenta. Przykładowo przyjechał do Warszawy dzień przed rozpoczęciem nauki, aby wybrać optymalny sposób przejazdu z miejsca zakwaterowania na uczelnię i wielokrotnie odbyć podróż na tej trasie; dzięki tym ćwiczeniom uzyskał pewność, że będzie docierał na poranne zajęcia punktualnie i bezpiecznie. Podobnych przygotowań wymagało poznanie rozmieszczenia poszczególnych sal i ważnych miejsc (szatni, dziekanatu, biblioteki, stołówki itp.) w budynkach uczelni. Wydarzeniem, które omal nie doprowadziło do przerwania nauki, było niespodziewane całkowite odwarstwienie się siatkówki lewego oka.

Na początku drugiego roku studiów nagle w ciągu jednego czy dwóch dni straciłem prawie całkowicie widzenie w jednym oku. I to mnie zaszokowało. Bo wyobrażałem sobie, że ta utrata wzroku może wcześniej czy później u mnie nastąpić w wyniku jaskry i innych problemów, natomiast w ogóle nie liczyłem się z tym, że nagle może odwarstwi mi się siatkówka i nagle ten wzrok stracę. I to był taki moment, w którym dosyć trudno było mi się z tym pogodzić. To był taki okres dwóch, trzech dni takiego zniechęcenia, gdzie w ogóle 
człowiekowi przestało się chcieć żyć. Znowu pod górkę, znowu problemy. Nawet u mnie w domu moja żona i córka powiedziały, że to już koniec z jeżdżeniem do Warszawy na studia... Ale ja jednak, jak już się czegoś podejmę, to staram się to doprowadzić do końca, i ja jednak zdecydowałem, że nie odpuszczę, że skończę te studia, dlatego że zbyt dużo mnie to kosztowało czasu, wysiłku i zdrowia... Stwierdziłem, że trzeba żyć dalej, i w tej chwili nie mam już problemu z tym, że nie widzę na jedno oko. Trzeba też przyznać, że to oko było i tak słabe, ono było takie wspomagające moje widzenie, gdzieś tam podglądałem nim coś, ale dobrze nie widziałem... Teraz mam problem, bo wchodzę w futryny $\mathrm{z}$ lewej strony, bo gdzieś to drugie oko w takich sytuacjach mi pomagało, potykam się o idących ludzi, bo źle ocenię odległość, czegoś tam z tej lewej strony mi brakuje.

Mimo stopniowo następującej utraty widzenia badany ukończył studia drugiego stopnia w terminie, broniąc pracę magisterską z zakresu tyflopedagogiki na ocenę dobrą. W momencie udzielania wywiadu złożył aplikację na studia podyplomowe.

\section{Podsumowanie}

W przedstawionym powyżej studium przypadku uderzający jest brak profesjonalnej pomocy tyflopedagogicznej na poszczególnych etapach drogi edukacyjnej osoby stopniowo tracącej wzrok przy jednoczesnej wysokiej motywacji badanego do zdobycia wykształcenia mimo napotykanych trudności. Wsparcie ze strony członków najbliższej rodziny (w dzieciństwie rodziców i starszego brata, w wieku dorosłym zaś żony i córki) okazało się najistotniejszym spośród czynników środowiskowych, które przyczyniły się do efektywnego przezwyciężania problemów edukacyjnych wynikających z progresywnej słabowzroczności. Wśród czynników osobowych znaczące okazały się takie cechy, jak: ambicja, wytrwałość, pracowitość, inteligencja, wysokie umiejętności interpersonalne. Co ciekawe, sam badany uważa, że niedostatek specjalistycznej pomocy i wiążąca się z tym konieczność samodzielnego mierzenia się z wieloma trudnymi sytuacjami, paradoksalnie, odegrały pozytywną rolę w procesie jego przystosowywania się do funkcjonowania z uszkodzonym wzrokiem. Badany wypracował bowiem szereg rozmaitych strategii radzenia sobie z problemami i potrafił je elastycznie dobierać do konkretnej sytuacji, przezwyciężył także początkowe bariery emocjonalne, które nie pozwalały mu na zwrócenie się o pomoc czy egzekwowanie należnych mu praw. Ustawiczne kształcenie stało się dla niego główną osią jego osobistego planu biograficznego. 


\section{Bibliografia}

Brzezińska A.I., Jabłoński S., Ziółkowska B. (2014). Specyficzne i specjalne potrzeby edukacyjne. „Edukacja”, nr 2 (127), s. 37-52.

Budziszewska M., Olender E., Gołuchowska M., Kocik D., Mućka J. (2015). Pamięć szkoły PRL-u. Badanie z wykorzystaniem technik narracyjnych. „Psychologia Wychowawcza", nr 7, s. 62-81.

Chrzanowska I. (2015). Pedagogika specjalna. Od tradycji do współczesności. Kraków: Oficyna Wydawnicza Impuls.

Czerwińska K. (2014a). Słabowzroczność a realizacja zadań rozwojowych w okresie adolescencji. W: Gunia G., Baraniewicz D. (red.). Teoria i praktyka oddzialywań profilaktyczno-wspierających rozwój osób z niepetnosprawnością. Tom 3.1. Kraków: Wydawnictwo Naukowe Uniwersytetu Pedagogicznego.

Czerwińska K. (2014b). Uczeń z niepełnosprawnościa wzroku we współczesnej przestrzeni edukacyjnej. W: Suświłło M., Fechner N.A. (red.). Podmioty, środowiska i obszary edukacyjne. Wyzwania i zagrożenia połowy XXI wieku. Poznań: Wydawnictwo WSB.

Dycht M. (2015). Edukacja włączająca uczniów z dysfunkcja wzroku w Polsce wdrażanie zobowiązań i analiza wątków zaniedbanych. „Niepełnosprawność i Rehabilitacja", nr 2, s. 34-49.

Głodkowska J. (2013). Uczniowie ze specjalnymi potrzebami edukacyjnymi - integracja edukacyjna procesem złożonym i trudnym. „Szkoła Specjalna”, nr 1 (267), S. 5-16.

Gołębiowska B., Bargiel-Matusiewicz K. (2015). Zdrowie a wzrost potraumatyczny i duchowość. W: Bargiel-Matusiewicz K., Tomaszewski P., Pisula E. (red.). Kulturowe oraz społeczne aspekty zdrowia i obrazu ciała. Warszawa: Wydawnictwo UW.

Łuba M. (2015). Poradnictwo psychologiczne dla osób z niepełnosprawnością. W: Czabała C., Kluczyńska S. (red.). Poradnictwo psychologiczne. Warszawa: Wydawnictwo Naukowe PWN.

Marcinkowska B. (2015). Kształcenie uczniów z niepetnosprawnościa w Polsce - przeszłość, teraźniejszość, przyszłość. „Psychologia Wychowawcza”, nr 7, s. 205-219.

Melchior M. (2008). Wymiary złożonej tożsamości jednostkowej. Kategorie teoretyczne na przykładzie osób słabowidzacych. W: Mucha J., Pactwa B. (red.). „Status mniejszościowy" i ambiwalencja tożsamości w społeczeństwach wielokulturowych. Tychy: PTS.

Smith D.D. (2008). Pedagogika specjalna. Podręcznik akademicki, cz. 2. Warszawa: Wydawnictwo APS, Wydawnictwo Naukowe PWN.

Zaorska M. (2015). Tyflopedagog wobec problemu aktywności życiowej-zawodowej i prozawodowej osób dorostych $z$ niepetnosprawnościa wzrokowa. Toruń: Wydawnictwo Edukacyjne Akapit. 


\title{
INDIVIDUAL WITH PROGRESSING VISION LOSS - FUNCTIONING IN THE AREAS OF EDUCATION AND REHABILITATION
}

\begin{abstract}
The text consists of two parts: the first part contains a theoretical analysis of the impact that congenital progressive condition has on the life of an individual, with particular emphasis on such areas as education and social functioning; in the second part a case study is presented illustrating the education process of an individual with progressing low vision, seen against the background of political and social changes which occurred in Poland over the last forty years.
\end{abstract}

Key words: visual impairment, loss of vision, education, rehabilitation

Kornelia Czerwińska - doktor nauk humanistycznych w dyscyplinie pedagogika, pedagog specjalny (tyflopedagog) i psycholog, adiunkt w Zakładzie Tyflopedagogiki Wydziału Nauk Pedagogicznych APS. Adres do korespondencji: Wydział Nauk Pedagogicznych, ul. Szczęśliwicka 40, 02-353 Warszawa. Adres e-mail: kczerwinska@aps.edu.pl. 